\title{
Budding of Current Season Seedlings of Pistacia vera L. During Different Times in Late Summer
}

\author{
Aram Akram Mohammed ${ }^{1, a, *}$ \\ ${ }^{1}$ Horticulture Department, College of Agricultural Engineering Sciences, University of Sulaimani, Kurdistan Region, Iraq \\ *Corresponding author \\ A R T I C L E I N O A B S T R A C T \\ Research Article \\ Budding of Pistacia vera L. seedling at the earlier stage of growth with a certain sex type scion is \\ very important because $P$. vera vegetative growth stage is long and requires more time to produce \\ fruit to determine the sex type of the trees. Therefore, the current experiment was carried out to \\ determine the best time for budding current seedlings of $P$. vera during late summer. The budding \\ Received : 10/08/2021 \\ Accepted : 28/11/2021 \\ times were 20 Aug., 1 Sept., 10 Sept., and 20 Sept in 2020, and the seedlings were between 5-6 \\ months along budding times. The results revealed that the highest budding success $(50 \%)$ was \\ achieved from the seedlings budded on 20 September followed by those seedlings budded on 10 \\ September $(38.88 \%)$. While, budding success percentage was the lowest in the seedlings budded on \\ 20 August and 1 September with the same ratio (27.77\%). The longest shoot and the thicker shoot \\ diameter $(19.30 \mathrm{~cm}$ and $4 \mathrm{~mm}$, respectively) were achieved in the seedlings which budded on 10 \\ Keywords: \\ Pistacia vera \\ Vegetative growth \\ Current season seedlings \\ T-budding \\ Late summer \\ September. In contrast, shoot length was the shortest $(3.93 \mathrm{~cm})$ in seedlings that were budded on 20 \\ August, and shoot diameter was almost similar $(2.39,2.23$ and $2.72 \mathrm{~mm})$ in all seedlings budded on \\ 20 August, 1 September and 10 September, respectively. This study showed that 20 September was \\ the best time for conducting budding of $P$. vera seedlings which were produced in nursery black \\ bags in the current season.
}

aram.hamarashed@univsul.edu.iq (D)https://orcid.org/0000-0002-4421-3556|

(c) () () T) This work is licensed under Creative Commons Attribution 4.0 International License

\section{Introduction}

Pistachio (Pistacia vera L.) is a dioecious tree species from Anacardiaceae family and native to western Asia and Asia Minor, and the Mediterranean regions of Europe and North Africa, the Middle East and California are the regions of $P$. vera cultivation over a large range (Hormaza and Polito, 1996; Pérez-López et al., 2018; Torun et al., 2021). It requires warm, dry summers and relatively cold winters; it is very resistant to drought conditions (Al Barazi and Schwabe, 1982; Kaska, 2002). Pistachios are often propagated through seeds in large numbers (Al-Imama and Al-Jubury, 2011). Whereas, seed propagation is unfavorable for $P$. vera propagation because the growth of seedlings from seed is slow and requires more time to reach the size of grafting and bearing fruit (Arpaci et al., 1998). On the other hand, morphological discrimination between the sex type of the seedlings or trees from the seeds along the juvenile and vegetative phase is difficult and not reliable (Bai et al., 2019). For this reason, budding is conducted to the seedlings or saplings with a certain sex type to hasten bearing (El-Deen and Abd El-Rhman, 2011).
Alternatively, sowing and growing of the seedling in pot is used for $P$. vera, then budded in fall or next spring and start to bear fruits in the following 4-5 years (Acar et al., 2011). However, Talaie and Panahi (2002) referred that most budding processes are done in the next or more years. Moreover, Kaska (2002) reported that middle east farmers prefer to bud the seedlings after waiting and growing for several years.

The rootstocks used for budding are $P$. atlantica, $P$. chinensis, $P$. integerrima, $P$. khinjuk, P. lentiscus, $P$. mutica, $P$. palaestina and $P$. terebinthus (Barghchi and Alderson, 1989), besides, for new orchards, P. vera is widely used as rootstock, due to this species produces more roots, thicker stems and reaches budding size in a shorter time (Ayfer et al., 1990). One of the critical demands for a successful budding process in $P$. vera is budding time. $P$. vera has resin and gumming exudation which is considered to be an obstacle for a successful budding process (Chatibi et al., 1995; Noori et al., 2019), therefore pistachio budding should be done during the times in which resin flow is at 
the lowest level. Hartmann et al. (2011) mentioned that the best time for doing $P$. vera budding is summer and fall, but spring is not appropriate because of excessive sap flow. Whereas, Holtz et al. (2005) indicated that gumming during early summer can be a problem for budding of $P$. vera. In this context, the objective of this experiment is to find out which time is the best for doing budding current season seedlings of $P$. vera $\mathrm{L}$. which grown in nursery black bags in late summer.

\section{Materials and Methods}

This experiment was conducted in Khurmal sub-town (35 $\left.18^{\prime} 00.0^{\prime \prime N} 46^{\circ} 02^{\prime} 20.4^{\prime \prime E}\right)$, Halabja province, Kurdish Region-Iraq to investigate the effect of different late summer budding times on the budding success process of Pistacia vera $\mathrm{L}$. current season seedlings.

Mature seeds of Pistacia vera $\mathrm{L}$. were sowed on $2 / 3 / 2020$ in $1: 1$ sand and decomposed manure medium. After about 25 days, the germinated seeds were transplanted to $20 \times 30 \mathrm{~cm}$ black plastic nursery bags containing a mixture of $1: 1: 1 \mathrm{v} / \mathrm{v}$ soil, sand and manure. After one month from transplanting (on 24/4/2020), the seedlings were fertilized one time with $1 \mathrm{~g}$ per bag $\mathrm{N}$ fertilizer. 25 days following $\mathrm{N}$ fertilizer, also the seedlings were fertilized with $3 \mathrm{~g}$ per bag NPK fertilizer two times at 25 days interval. The seedlings were maintained, irrigated at 2 days intervals during summer, and the diameter of the seedling reached around 7-5 $\mathrm{mm}$ at $5 \mathrm{~cm}$ above the growing media (from plastic bag edge), during the times of the budding.

The budding process was conducted four times in late summer 2020 (20 Aug., 1 Sept., 10 Sept. and 20 Sept.), by T-budding pattern. Well-developed scions were taken from one-year-old shoots of 'Batoury' cultivar with a similar diameter of the seedling rootstocks $(7-5 \mathrm{~mm})$. The scions were taken on 10 September were male. The experiment was laid out in CRBD with three replications and in each replication 12 seedlings were budded, and in each budding time 36 seedlings were budded.

Finally, on 5/5/2021 the parameters of budding success percentage, shoot length and diameter of sprout scions was taken. The results were analyzed using XLSTAT computer program, and the means were compared by Duncans multiple ranges $5 \%$.

\section{Result}

The data in figure (1) showed that late summer budding times were significantly effective to achieve a successful budding percentage from current season seedlings of Pistacia Vera (the seeds were sown in late winter and budded in late summer of the same year). Budding success percentage increased from late August to late September. The highest budding success $(50 \%)$ was obtained from the seedlings budded on 20 September but not significantly by those seedlings budded on 10 September (38.88\%). While, budding success percentage was the lowest in the seedlings budded on 20 August and 1 September, both gave the same budding success $(27.77 \%)$.

The shoot length and diameter of the sprout scion were noticeably different according to budding times (Figure 2).

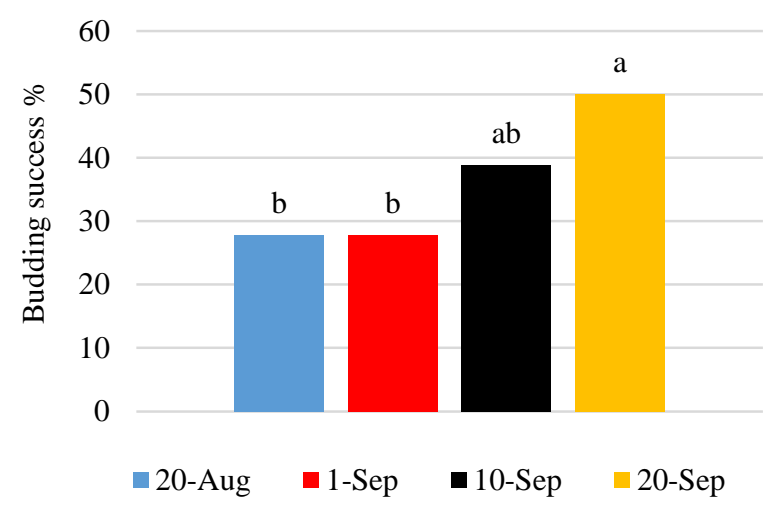

Figure 1. Budding success percentage of current season seedlings of Pistacia vera $\mathrm{L}$.

The same letter indicates that there is no significant difference, Duncan's multiple range tests $(\mathrm{P}<0.05)$.

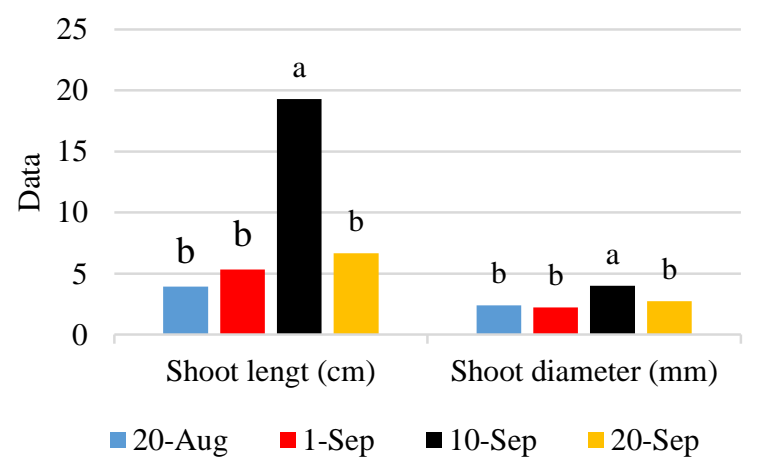

Figure 2. Shoot length $(\mathrm{cm})$ and shoot diameter $(\mathrm{mm})$ of sprout bud of budded Pistacia vera L. current season seedlings.

The same letter indicates that there is no significant difference, Duncan's multiple range tests $(\mathrm{P}<0.05)$.

The longest sprout shoot $(19.30 \mathrm{~cm})$ was achieved in the $P$. vera seedlings of the current season which budded by T-budding pattern on 10 September, also the same seedlings gave the highest shoot diameter $(4 \mathrm{~mm})$. In contrast, shoot length was the shortest $(3.93 \mathrm{~cm})$ in seedlings that were budded on 20 August, and shoot diameter was almost similar $(2.39,2.23$, and $2.72 \mathrm{~mm})$ in all seedlings budded on 20 August, 1 September and 10 September, respectively.

\section{Discussion}

Depending on the obtained results of this experiment, superiority percentage of budding success in late September, especially on 20 September. This result may be attributed to that temperature during this time is satisfactory for budding success, whereas temperature in late August, and early September was still somewhat high. In this context, Acar et al. (2011) concluded that T-budding of potted $P$. vera at the end of September gave a more successful percentage of budding because of favorability of temperature, in opposite June and July budding is not better enough due to extreme temperature. Furthermore, Baryla and Kaplan (2012) described that budding success is significantly influenced by budding time depending on environmental and climatic conditions. 
The longest shoot on 10 September might be due to differences between this budding time in sex type of the budded scion compared with the scions were budded in other times, the scions taken on 10 September were male but in other times were female. It is observed that male growth of $P$. vera is somewhat vigorous in comparison to female ones. Parfitt et al. (2010) mentioned that 'Randy' male pistachio trees demonstrated vigorous growth compared to the female ones. Aside from that, some of the seedlings that were budded on 20 August started to sprout budded scions about 25 days after budding, but this did not occur with other budding times, the other budding times remained dormant along the fall and winter seasons and started to sprout in the spring. This might belong to that the budded seedlings on 20 August succeeded earlier in which still climatic conditions were favorable to sprout the budded scions.

\section{Conclusion}

The best time for budding Pistacia vera $\mathrm{L}$. seedling of the current season was 20 September in late summer budding time. Additionally, a vigorous shoot length and shoot diameter were found in the seedlings that were budded on 10 September.

\section{References}

Acar I, Arpaci S, Sarpkaya K, Karadağ S, Karayilan A. 2011 Improving the budded and potted pistachio young plant production in Firat Valley. Acta Hort., 912: 239-244.

Al Barazi Z, Schwabe WW. 1982. Rooting softwood cuttings of adult Pistacia vera. Journal of Horticultural Science, 57(2): 247-252.

Al-Imama NMA, Al-Jubury YMS. 2011. Response of seed germination and subsequent seedling growth of Aleppo pistachio cultivar 'Ashoury' (Pistacia vera L.) to different growing media. Acta Hort., 912: 245-252.

Arpaci S, Aksu O, Tekin H. 1998. Determination of the best suitable grafting method on different pistachio rootstocks. Acta Hort., 470: 443-446.

Ayfer M, Okay Y. Erdogan V. 1990. Antepfistigi anaclari ve cogaltilmalari. Turkiye 1. Antepfistigi Simpozyumu Bildirileri, 11-12 Eylul 1990- Gaziantep, pp: 38-48.

Bai Q, Ma Z, Zhang Y, Su S, Leng P. 2019. The sex expression and sex determining mechanism in Pistacia species. Breeding science, 69: 205-214.
Barghchi M, Alderson PG. 1989. Pistachio (Pistacia vera L.). In Trees II (pp. 68-98). Springer, Berlin, Heidelberg.

Baryła P, Kapłan M. 2012. The effect of the time of budding of mahaleb cherry (Prunus mahaleb L.) seedlings on the quality of maiden trees of sour cherry (Prunus cerasus L.) 'ŁUTÓWKA'. Acta Agrobotanica, 65(4):163-168.

Chatibi A, Kchouk ME, Ben Abdallah F, Zemni H, Ghorbel A. 1995. Rooting improvement of Pistacia vera $\mathrm{L}$. cv. Mateur by in vitro culture of apices and cuttings. Acta Hort., 419: 213-220.

El-Deen EZ, Abd El-Rhman IE. 2011. Studies on Grafting Methods and Dates of Pistachio Trees Under Supplemental Irrigation in North Sinai. Research Journal of Agriculture and Biological Sciences, 7(6): 456-463.

Hartmann HT, Kester DE, Davies JrFT, Geneve RL. 2011. Plant Propagation: Principles and Practices (8th ed.). New Jersey: Prentice Hall, 915 p.

Holtz B, Ferguson L, Parfitt D, Allen G, Radoicich, R. 2005. Pistachio Production Manua, Rootstock production and budding. Cooperative extension, University of California, Oakland, CA, USA, pp. 74-79. http://fruitsandnuts.ucdavis.edu/dsadditions/Pistachio_Manu al_2005/.

Hormaza JI, Polito VS. 1996. Pistillate and staminate flower development in dioecious Pistacia vera (Anacardiaceae). American Journal of Botany, 83(6): 759766.

Kaska, N. 2002. Pistachio nut growing in the Mediterranean basin. Acta Hort., 591: 443-455.

Noori IM, Ahmad FK, Azizn RR, Mohammed AA. 2019. Propagation of pistachio Pistacia vera $\mathrm{L}$. by air layering under the effects of IBA and GA 3 treatments. EurAsian Journal of BioSciences, 13(2): 2001-2004.

Parfitt DE, Kallsen CE, Holtz B, Maranto, J. 2010. 'Randy'male pistachio. HortScience, 45(7): 1113-1115.

Pérez-López D, Memmi H, Gijón-López MC, Moreno MM, Couceiro JF, Centeno A, Martín-Palomo MJ, Corell M, Noguera-Artiaga L, Galindo A. 2018. Chapter 11-Irrigation of Pistachios: Strategies to Confront Water Scarcity. In Water Scarcity and Sustainable Agriculture in Semiarid Environment; García Tejero, I.F. and Durán Zuazo, V.H., Eds.; Academic Press: Cambridge, MA, USA, pp. 247-269.

Talaie A, Panahi B. 2002. Pistachio growing in Iran. Acta Hor., 591: 133-138.

Torun AA, Bozgeyik S, Duymuş E. 2021. The Effect of Boron Application in Increasing Doses on Shoot Boron Concentration and Uptake of Other Nutrients of Pistachio (Pistacia vera L.). Turkish Journal of Agriculture-Food Science and Technology, 9(5): 855-862. 